\title{
Prevalence and Morpho-Anatomical Diversity of Arbuscular Mycorrhizal Fungi Spores, from Soybean (Glycine max L.) Rhizosphere in the Agro-Ecological Zone 1 of Cameroon
}

\author{
Richard Tobolbaii ${ }^{1}$, Albert Ngakou ${ }^{2}$, Steve Tatoukam Toukam ${ }^{2}$
}

\author{
${ }^{1}$ Department of microbiology, Faculty of Science, University of Yaoundé 1, Laboratory of Mycrobiology, BP 812 \\ Yaoundé \\ ${ }^{2}$ Department of biological Sciences, Faculty of Science, University of Ngaoundere, Laboratory of biodiversity and \\ Sustainable Development. Biofertilizer and Bioinsecticide Unit, BP: 154, Ngaoundere, Cameroom
}

\begin{abstract}
This work investigates on the morpho-anatomical diversity of arbuscular mycorrhiza fungus spores native to soybean rhizosphere in the agro-ecological zone I of Cameroon. Arbuscular mycorrhiza fungi spores have been trapped in pot on composite soils samples taken from three areas in each northern region. Soybean have been used as host plant. After 90 days of growth, the mycorrhizal fungus spores have been extracted and the host plant roots stained. Results analysis revealed that the mycorrhization frequency $(\mathrm{F})$ and intensity (I) are higher at Maroua area $(\mathrm{F}=4.6 \%, \mathrm{I}=3.95 \%)$ and lower at Guider zone $(\mathrm{F}=1.33 \%$ and $\mathrm{I}=1.22 \%)$. For the specific density, the values vary between 1.54\% (Guider zone) and 5.2\% (Yagoua zone). Regarding the specific richness, the obtained data fluctuate between 3\% (Guider) and 8\% (Mokolo). The morpho-anatomical characterization of the spores indicated the presence of 9 different specimens: Septoglomus constrictum, Glomus maculosum, Glomus manihostis, Acaulospora kentinensis, Acaulospore myriocarpa, Rhizophagus intraradices, Ambispora sp. Funneliformis mossea, Diversispora epigae. Among these strains, Septoglomus constrictum is the most abundant specimen while Funneliformis mossea, Ambispora sp and Acaulospora myriocarpa are the rarest. The agronomic performances of these strains can be evaluated for and ecological production of soybeans in the agro-ecological zone I of Cameroon.
\end{abstract}

Keyswords: sAgro-Ecological Zone 1, Specfic Density, Specific Richness, Mycorrhization Frequency, Myorrhization Intensity

\section{Introduction}

Arbuscular mycorrhizal symbiosis is the most common plant-microorganism symbiosis in plants kingdom (Strullu, 1991). The most appreciable advantage of this symbiosis is the uptake and transfert to plants, of some nutrients which are less available in the soil, mainly phosphorus (Lambers and al., 2008). This nutrients acquirement also concerns $\mathrm{N}, \mathrm{K}, \mathrm{Mg}, \mathrm{Na}, \mathrm{S}, \mathrm{B}, \mathrm{Cl}$, (Caris and al., 1998). A mycorrhized plant shows a better resistance against environmental stresses, including drought (Subramanian and al., 1995), cold (Charest and al., 1993), high salinity (Davis and Young, 1985) and pollution (Leyval and al., 1995). In addition, mycorrhization reduces the incidence of root diseases and minimizes the harmful effect of some pathogenic microorganisms, (Dehne, 1982). This performance of mycorrhized plants in drawing soil nutrients and resisting to environmental stresses, grants to fungal symbionts a function of biofertilizer and crop protection agent (Dalpé, 2005). However, an appropriate knowledge of the arbuscular mycorrhiza communities structure and diversity, is crucial for the enhancement of their agronomic and environmental potentialities; particularly in tropical agroecosystems (including Cameroon), (Cardoso and Kuyper 2006; Lovera and Cuenca, 2007). In fact, Cameroon has a great climate diversity, due to its geographical position, and which allows it to be subdivided into 5 agro-ecological zones (FAO, 2008). The agroecological zone 1 on which our study is focused, covers the Far North region, the North and part of the North of the Adamawa region. This party of Cameroon is characterized by low rainfall, and the period of plant growth varies from 14 to 184 days (FAO, 2009). Among the severall crops cultivated in this area, soybean is cited among the most widely cultivated legumes (FAO, 2009). Due to its exceptional nutritional qualities, the production and consumption of soybean deserve to be encouraged (Anonymous, 2016). Indeed, its grains have a very high fat content $(20 \%)$ and very good nutritional protein $(35 \%)$. The are particularly rich in lysine, which is an essential amino acid. Soybean can replace proteins from milk, meat, fish, eggs, (Anonymous, 2016). This work is an analysis of the 
prevalence and diversity of endigenous fungi associated with soybeans in agro-ecological zone 1 of Cameroon.

\section{Material and Methods}

an intensive degradation, where rainfoll is reduced to 3 months and the dry season lasts at least 7 months. The precipitation varying between 500 and $1000 \mathrm{~mm}$

\section{Experimental site}

This work have been carried out in the agroecological zone 1 of Cameroon which includes the the Far North region, the North and part of the North of the Adamawa region. It is an erea whith per year. The average temperature is $28^{\circ} \mathrm{c}\left(21^{\circ}-34^{\circ}\right)$. The plants growth period varies between 14 to 184 days (FAO, 2009).

Table 1: Geographical and climatological data of study site

\begin{tabular}{|c|c|c|c|c|c|c|c|}
\hline Regions & Sampled zones & $\begin{array}{l}\text { Sampled } \\
\text { fields }\end{array}$ & $\begin{array}{l}\text { Altituds } \\
\text { (m) }\end{array}$ & Latituds & Longituds $^{\circ}$ & $\begin{array}{l}\text { Rainfalls } \\
\text { (mm/year) }\end{array}$ & $\begin{array}{c}\text { Temperatures } \\
{ }^{\circ} \mathbf{c}\end{array}$ \\
\hline \multirow{3}{*}{ Adamawa } & \multirow{3}{*}{ Ngaoundéré } & Field 1 & 1211 & 07.27041 & 13.55515 & \multirow[b]{2}{*}{$225-285$} & \multirow[b]{2}{*}{$12-30$} \\
\hline & & Field 2 & 1090 & 07.41049 & 13.54827 & & \\
\hline & & Field 3 & 1155 & 07.46221 & 13.59745 & \multirow{19}{*}{$500-1000$} & \multirow{19}{*}{$17-40$} \\
\hline \multirow{9}{*}{ Far North } & \multirow{3}{*}{ Mokolo } & Field 1 & 326 & 10.58731 & 14.00415 & & \\
\hline & & Field 2 & 317 & 10.7412 & 13.7986 & & \\
\hline & & Field 3 & 371 & 10.86547 & 13.89596 & & \\
\hline & \multirow{3}{*}{ Maroua } & Field 1 & 408 & 10.61877 & 14.35906 & & \\
\hline & & Field 2 & 482 & 10.53025 & 14.13976 & & \\
\hline & & Field 3 & 357 & 10.53077 & 14.93538 & & \\
\hline & \multirow{3}{*}{ Yagoua } & Field 1 & 357 & 10.28578 & 14.93538 & & \\
\hline & & Field 2 & 357 & 10.32601 & 15.24176 & & \\
\hline & & Field 3 & 331 & 10.49614 & 15.18793 & & \\
\hline \multirow{9}{*}{ North } & \multirow{3}{*}{ Guider } & Field 1 & 494 & 9.95649 & 13.62433 & & \\
\hline & & Field 2 & 384 & 9.92437 & 13.93035 & & \\
\hline & & Field 3 & 298 & 8.76711 & 13.35941 & & \\
\hline & \multirow{3}{*}{ Garoua } & Field 1 & 247 & 9.30813 & 13.8870 & & \\
\hline & & Field 2 & 327 & 9.02162 & 13.49671 & & \\
\hline & & Field 3 & 295 & 9.31311 & 13.36625 & & \\
\hline & \multirow{3}{*}{ Tcholiré } & Field 1 & 311 & 8.38526 & 14.17865 & & \\
\hline & & Field 2 & 401 & 8.41254 & 14.17865 & & \\
\hline & & Field 3 & 297 & 8.52431 & 14.10856 & & \\
\hline
\end{tabular}

\section{Soils sampling}

Soils samples have been collected in three zones, randomly chosen per region, considering the accessibility aspect; and in each zone, three fields have been also randomly chosen. The selected field per zone are at least 10 kilometers apart. During the soil collection exercise, approximately $10 \mathrm{~kg}$ of soil have been taken between $05-10 \mathrm{~cm}$ deep per field. The sampled soil have been mixed up in each zone to obtain a single composite soil.

\section{Physico-chemical characteristics of soils samples}

The physico-chemical properties of the soil samples have been evaluated using the Palintest Kit with a 5000 photometer. The evaluated parameters are: Sand content, silt content, clay content, $\mathrm{pH}$, conductivity, organic carbon (CO), organic matter (OM), phosphorus $(\mathrm{P})$, Magnesium $(\mathrm{Mg} 2+)$ and Calcium $(\mathrm{Ca}+)$. These analyzes have been carried out at the Soil-Water-Plants Analysis Laboratory (ITRAD) (Chadian Institute of Agronomic Research for Development).

\section{Trapping of mycorrhiza fungus spores}

The multiplication of the spores have been realised according to the method of Brundrette and al. (1996) adjusted as follows; Soybean seeds have been sown in pot (2 liters capacity). For each composite soil sample type, five pots have been used. The used seeds have been obtained from local farmers and three have been sown per pot. The pots have been placed out of ground contact, sheltered from the wind, and watered directly with rainwater for three months. At this moment, the above-ground biomass have been eliminated, while the roots and the soil substrate have been taken to the Laboratory for analyzes. The roots have been removed, stored in the fridge at $4{ }^{\circ} \mathrm{C}$ while waiting to be analyzed.

\section{Roots staining}

Fine harvested soybean roots have been thinned according to the method of Hayman, (1970), to assess endomycorrhizal infestation structures. Youngest roots have been cut into 1-2 cm length, they were then successfully washed, inserted into a test tube containing $10 \%$ potassium hydroxide, and heated in a water bath at $90^{\circ} \mathrm{C}$ for 30 minutes to clear the roots. Potassium hydroxide was eliminated then, the solution was filtered through a sieve before neutralization by rinsing with acidified water. Neutralized roots were mixed into cotton blue under a water bath for 15 minutes, filtered again through a sieve and rinsed with distilled water. Some roots were mounted in water for direct observations, while other were mounted in glycerine for later 
observations.

\section{Estimation of mycorrhization}

The mycorrhization estimation parameters were evaluated according to the method of Sghir and al. (2013).

\section{a). The mycorrhization frequency}

The frequency or percentage of mycorrhization is the number of root fragments that have been found mycorrhized among the total number of the observed fragments.

$\mathbf{F}(\%)=100(\mathbf{N}-\mathbf{N} 0) / \mathbf{N} . \mathrm{N}$ is the number of fragments observed and N0, the number of nonmycrhized fragments, (Sghir and al., 2013).

\section{b). The mycorrhization intensity}

The mycorrhization intensity is the root cortex colonization density by arbuscular mycorrhiza fungi. It is evaluated by attributing each root fragment a score class between 0 and 5 according to the estimation of root cortex colonization by arbuscular mycorrhiza fungi: $0=$ No infection, $1=$ Trace of infection, $2=$ less than $10 \%, 3=10$ to $50 \%, 4=51$ to $90 \%, 5=$ More than $90 \%$.

I (\%): $((95 n 5+70 n 4+30 n 3+5 n 2+n 1)) / N$ while $\mathrm{n} 5, \mathrm{n} 4, \mathrm{n} 3, \mathrm{n} 2$ and $\mathrm{n} 1$ are the numbers of the roots noted from 1 to 5, (Sghir and al., 2013).

\section{Extraction of arbuscular mycorrhizal fungi spores}

The mycorrhizal spores have been extracted according to the wet sieving extraction method described by Gerdemenn and Nicolson, (1963) adjusted as follows: 1 . Mix a $500 \mathrm{~g}$ soil sample in 4 liters of distilled water; 2. Homogenize by mechanical stirring for $15 \mathrm{~min}$ (repeat this exercise 3 times); 3. Pass this solution through a series of sieves that have size corresponding to those of arbuscular fungi spores (25-50-100-200-300-400 microns); 4. After rinsing the sieves, recover and mix the residue from each sieve in a $60 \%$ sucrose solution, then create a density gradient by centrifugation at 3000 rpm; 5. Filter the supernatant through a 25 micron sieve and collect the spores in Petri dishes.

\section{Morphological classification of spores}

The extracted arbuscular fungal spores were collected in Petri dishes and placed under a binocular magnifying glass for observation. Using forceps, they were grouped by morphotypes under the criteria of size, color and shape.

\section{Determination of spore size}

The spores size have been determined according to the method of Walter, (2003) described as follows: a. The spore is mounted on a slide without being crushed; b. A graduated ruler is placed $25 \mathrm{~cm}$ from the slide and the lens of the magnifying glass; $c$. With one eye, the spore is observed through the eyepiece of the magnifying glass, while the other eye is focused on the ruler; $d$. Carefully superimpose the image of the spore on the graduated ruler to obtain the size of the image in centimeters, the appearant size (Ta). e. Determine the magnification of the loupe (GO):

GO = Objective $\mathbf{x}$ Eyepiece. In our case, objective $=$ 5.0 and eyepiece $10, \mathrm{GO}=50$. The real size of the object is: $\mathbf{T r}=\mathbf{T a} / \mathbf{G O}$, f. The size of the spore is obtained in centimeters and the conversion table have been used to asess the size in micrometers.

\section{Morpho-anatomical characterization of isolated spores}

After the determination of the shape, color and size of spores, they were mounted between slide and coverslip; one part in PVGL (Polyvinyl-Lactic AcidGlycerol), the other in PVGL-Melzer's Reagent (V:V/1:1) (Koske and Tessier, 1983). Morphological genera determination have been made based on descriptions of Morton and Beny, (1990). The original descriptions of the species as well as the information provided on the website of the International Vesicualar Mycorhizal fungi collection (INVAM)

(http: //invam.caf.wv.edu/taxonomy/speciesID.htm) have been used for identification of spores. The morphological characters of the spores described were compared with those of the original specimens description and reference strains.

\section{Estimation of arbuscular mycorrhiza fungal spores \\ a. Specific density}

The specific density is an estimation of the spores number in $100 \mathrm{~g}$ of soil sample. D (\%): N/ 100 where $\mathrm{N}$ is the number of spores counted and 100, the amount of soil used for their isolation (Sghir and al., 2013).

\section{b. Specific richness}

Specific richness is the number of different genus of arbuscular mycorrhiza fungal in a given CMA collection.

R (\%): 100 (Number of different arbuscular fungus genus) / (Total number of spore counted)

\section{c. Shanonne diversity index}

This value permits to assess the diversity level within the identified arbuscular fungi community.

$\mathbf{H}^{\prime}=-\sum$ pi.log2.pi where pi is the portion of the species $i$ in the total number of species ( $S$ ) in the study medium. $\mathbf{P}$ (i) is calculated as follows: $\mathbf{p}(\mathbf{i})=$ (ni)/ $\mathbf{N}$ where ni is the number of individuals for species $\mathrm{i}$ and $\mathrm{N}$ is the total population (Shanonne and Weaver, 1949). 


\section{Statistical analysis}

The data have been statistically analyzed using the "statgraphics 5.0" program which performs analysis of variance (ANOVA). The results averages from the different localities were separated using the least significant difference (LSD) at the threshold of the probabilities indicated. Pearson's correlation was used to analyze the correlations between the studied differents parameters. The links between the different parameters were determined by the Pearson correlation coefficient.

\section{Results}

\section{Soils physico-chemical properties}

Table 1 shows that all soil samples from the different zones of the three regions have an acidic $\mathrm{pH}$ (4.325.30). The degree of acidity is higher in the Yagoua zone (4.97) and less important in the Guider zone (5.30) ( $\mathrm{P}<0.001)$. For the phosphorus content, its value is higher at Ngaoundéré (94ppm) and lower at Garoua $(30 \mathrm{ppm})(\mathrm{P}<0.001)$. The granulometric parameters are also variable according to the study zones: It is the Mokolo zone which is the most sandy one $(73.20 \%)$, while it is that of Ngaoundéré which is the most clayey $(56.91 \%)$. ( $\mathrm{P}<0.001)$. Regarding the organic matter, significant difference was observed between the values, lower at Ngaoundéré $(0,095 \%)$ and Maroua $(0,0105 \%)$, and similar and higher in the other zones $(112-114 \%),(\mathrm{P}<0.001)$.

Tableau 1 : Physico-chemical properties of sampled soils

\begin{tabular}{|c|c|c|c|c|c|c|c|c|c|c|}
\hline & $\mathrm{pH}$ & Sand & Limon & Clay & Cond & C.O (\%) & M.O & $\mathbf{P}$ (ppm) & K (ppm) & Mg2+ \\
\hline Ngaoundéré & $5,00 \mathrm{~cd}$ & $20,28 b$ & $23,52 \mathrm{~d}$ & $56,19 \mathrm{~g}$ & $212 c$ & $0,055 \mathrm{a}$ & $0,095 \mathrm{a}$ & $94 \mathrm{f}$ & $330 \mathrm{a}$ & $185 \mathrm{e}$ \\
\hline Mokolo & $5,13 \mathrm{~d}$ & $73,20 \mathrm{~g}$ & $14,84 \mathrm{~b}$ & $11,91 a$ & $150,4 a$ & $0,067 \mathrm{bc}$ & $0,116 \mathrm{c}$ & $43 b$ & $405 b$ & $60 \mathrm{a}$ \\
\hline Maroua & $5,02 \mathrm{bcd}$ & $12,86 a$ & $42,62 f$ & $44,55 \mathrm{e}$ & $166,4 \mathrm{a}$ & $0,061 \mathrm{~b}$ & $0,0105 b$ & $72 d$ & $560 \mathrm{~d}$ & $410 \mathrm{f}$ \\
\hline Yagoua & $4,97 \mathrm{a}$ & $27,78 \mathrm{c}$ & $25,69 \mathrm{e}$ & $46,32 \mathrm{f}$ & $268 \mathrm{e}$ & $0,066 \mathrm{bc}$ & $0,114 \mathrm{c}$ & $43 b$ & $365 a$ & $115 c$ \\
\hline Tcholiré & 5,02 bcd & $71,52 \mathrm{f}$ & $15,68 \mathrm{c}$ & $12,79 \mathrm{~b}$ & $232 \mathrm{~d}$ & $0,065 \mathrm{bc}$ & $0,112 \mathrm{c}$ & $56 \mathrm{c}$ & $450 \mathrm{c}$ & $95 b$ \\
\hline Garoua & $4,98 \mathrm{a}$ & $71,10 \mathrm{e}$ & $14,00 \mathrm{a}$ & $14,89 \mathrm{c}$ & $250 \mathrm{f}$ & $0,065 \mathrm{bc}$ & $0,113 \mathrm{c}$ & $30 a$ & $450 \mathrm{c}$ & $180 \mathrm{e}$ \\
\hline Guider & $5,30 \mathrm{e}$ & $57,45 \mathrm{~d}$ & $15,60 \mathrm{c}$ & $26,93 \mathrm{~d}$ & $175,2 \mathrm{~b}$ & $0,066 \mathrm{bc}$ & $0,114 \mathrm{c}$ & $86 \mathrm{e}$ & $430 \mathrm{c}$ & $135 \mathrm{~d}$ \\
\hline P-value & $<0,001$ & $<0,001$ & $<0,001$ & $<0,001$ & $<0,001$ & $<0,001$ & $<0,001$ & $<0,001$ & $<0,001$ & $<0,001$ \\
\hline
\end{tabular}

C.O .: Organic carbon; M.O: Organic matter; cond: Conductivity, Ndéré: Ngaoundéré.

\section{Demonstration of endomycorrhizal symbiosis}

Thinning and staining of the soybean plants roots revealed the presence of some specific structures which characterized the endomycorrhial symbiosis. Figure 1 shows the structures observed (vesicles : A; hyphae: B ; endomycorrhiza spores : C). The spores are the structures that have been most observed. 

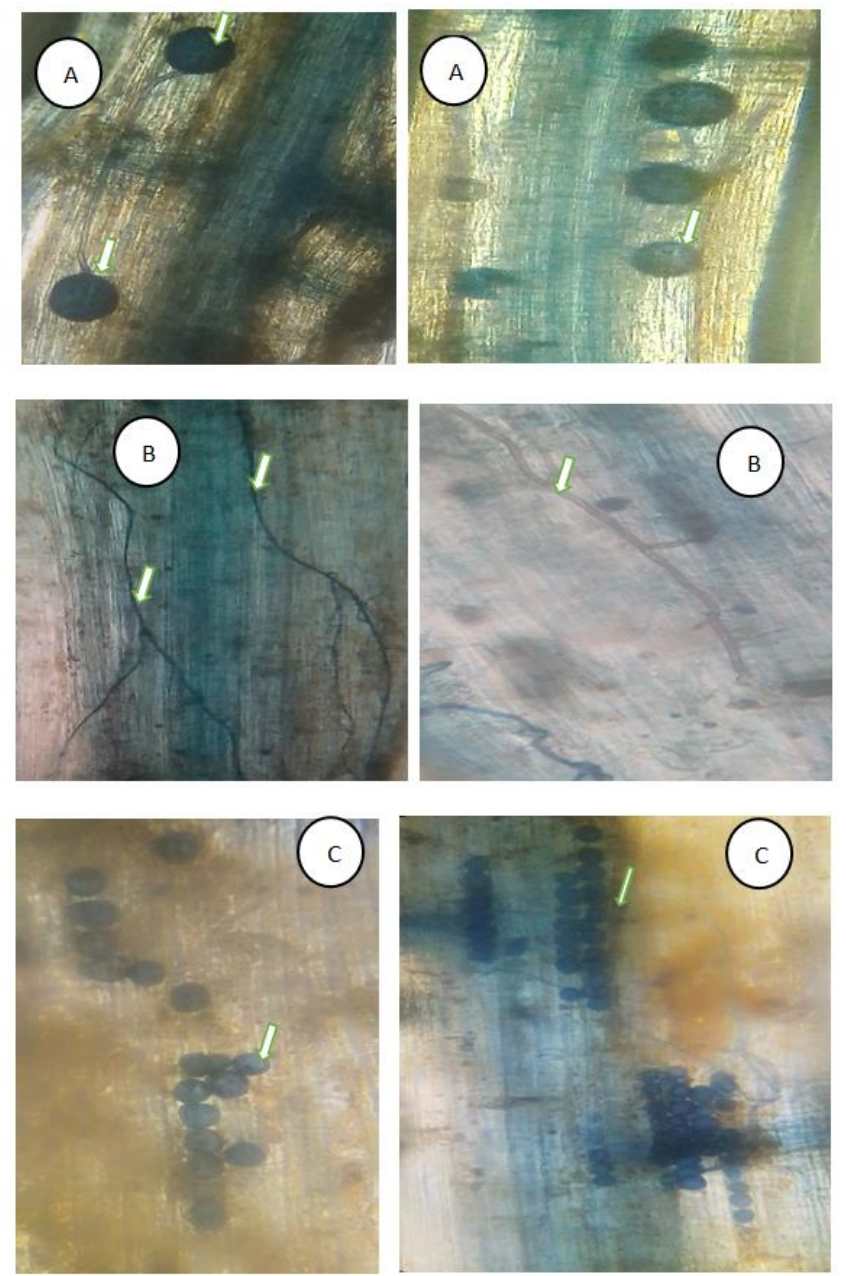

\section{The estimation of the mycorrhization a). Mycorrhization frequency}

Figure 2 indicates that the mycorrhization frequency is variable between the different study areas. The highest mycorrhization frequency was observed in the Maroua zone in the Far North (43.66\%), followed by those in the Ngaoundéré zone $(26.33 \%)$ in Adamawa and Tcholiré $(25,33 \%)$ in the North; conversely, the values recorded in the areas of Guider $(1.33 \%)$ and Garoua $(3 \%)$ in the North are similar and are lower ( $\mathrm{p}<0.0001)$. Nadjilom and al. (2019) have also obtained similar results on the morphological and structural diversity of the arbuscular mycorrhiza fungi community in rice rhizosphere, grown in the sahelian zone of Chad: Mycorrhization frequency variable between 4 and $7.33 \%$. These observations are lower than those of Gnamkoulamba and al. (2018) who recorded mycorrhization frequency values between $57-88 \%$ in a study on the diversity of arbuscular fungi in Togo. The variation of the mycorrhization frequency according to the sites can be justified by the history of particular land use of each site which negatively influences their mycorrhigenic potential; soils which have been cultivated for a very long time may see their mycorrhigenic potential greatly reduced, Głodowska and Wozniak, (2019).

Figure 1 : Mycorrhiztion structures (A: vesicules, B : Hypha, C : spores)

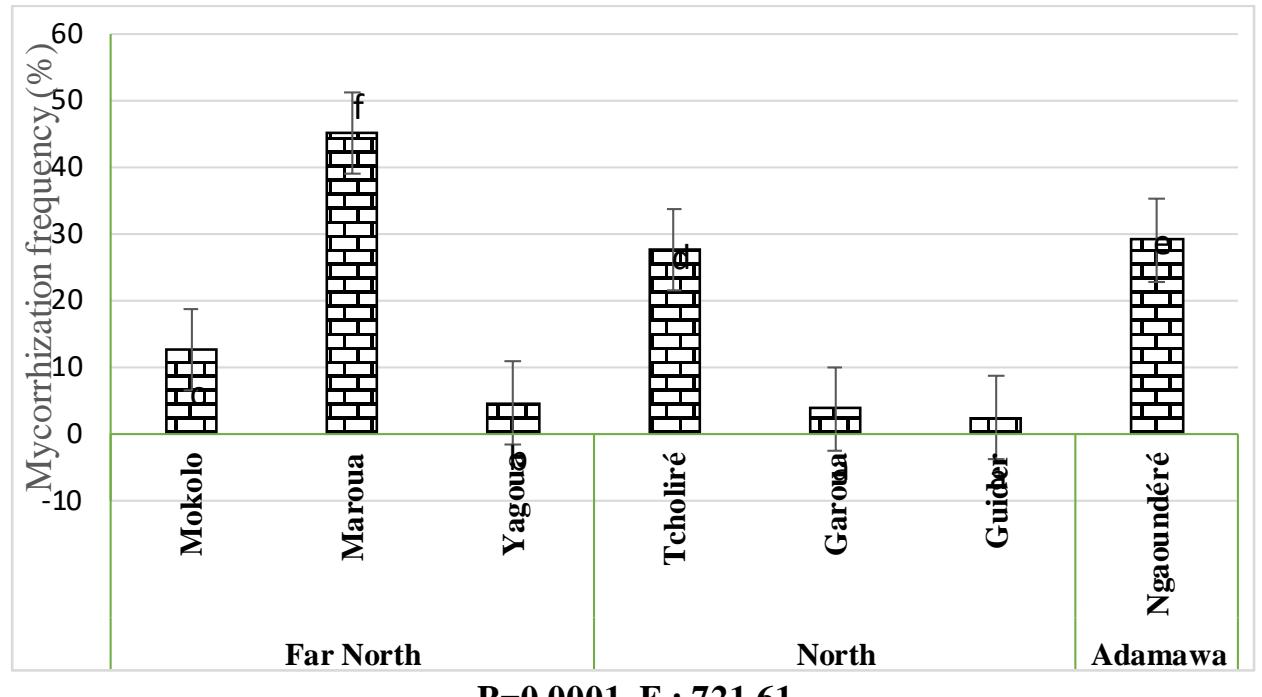

Figure 2 : Mycorrhization frequency

The mycorrhization frequency values are the average of three replications. Bars with the same letter are not significantly different at the indicated probability threshold.

\section{b. Mycorrhization intensity}

The variation of the mycorrhization intensity between the different study areas is illustrated in Figure 3. It have been noted that there is no significant difference 
between the mycorrhization intensities of the Guider areas $(1.22 \%)$, Garoua (3\%) in the North and Yagoua $(3.34 \%)$ in the Far North, and are lower compared to the values noted in the other zones. In addition, the intensities of the Tcholiré $(24.26 \%)$ and Ngaoundéré $(26.32 \%)$ zones are also similar and significantly lower than the value reported in the Maroua zone (39.55\%), (P<0, 0001). Tobolbaï and al. (2018) recorded similar mycorrhization frequency values, ranging from 1 to $20 \%$ during a study on the diversity of arbuscular mycorrhiza fungi spores associated with maize in North Cameroon. On the contrary, these data are inferior to those of Ouallal and $a l$. (2018) in Morocco who obtained an intensity of mycorrhization that fluctuates between 13 and $21 \%$ during a study on mycorrhizal fungi of the argan tree.

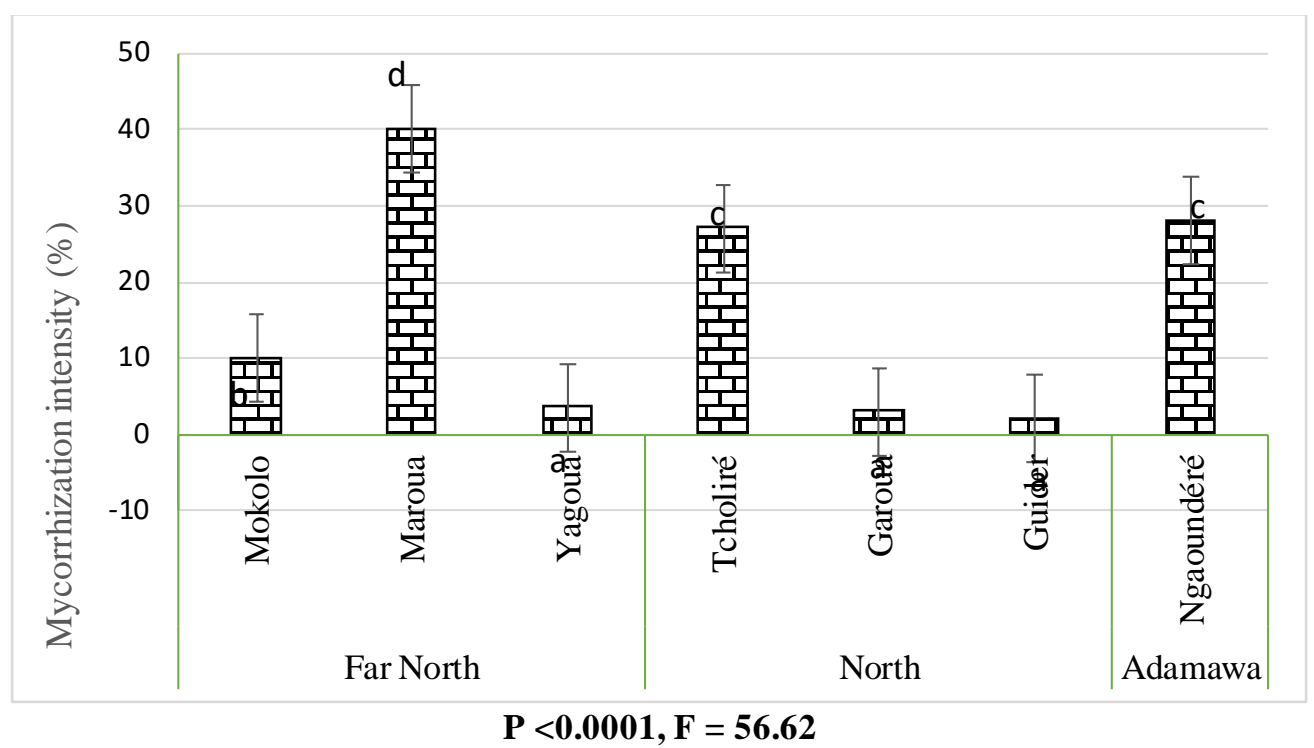

Figure 3: Soybean mycorrhization intensity

Mycorrhization intensity values are the means of three replicates. Bars with the same letter are not significantly different at the indicated probability threshold.

\section{Specific density}

Figure 4 shows that the specific density is variable depending of the study areas. Thus, the sporulation of arbuscular mycorrhiza fungi is greater in the Yagoua area $(5.20 \%)$ compared to the other study areas $(\mathrm{P}=$ $0.0001)$. The lowest spore densities were observed in the areas of Guider $(1.54 \%)$, Tcholiré $(2.61 \%)$ and
Mokolo $(2.04 \%)$ which are not significantly different. The data reported in the areas of Ngaoundéré $(3.65 \%)$, Garoua $(3.87 \%)$ and Maroua $(3.52 \%)$ are similar and are intermediate to the others. Similar specific densities have been reported by ZougariElwedi and $a l .(2012)$ in Tunisia where they recorded specific densities varying from 1 to $3 \%$ in the rhizosphere of date palm in the region of Djérid. Our results are lower than those of Ngonkeu and $a l$. (2013) who reported a specific density that fluctuates between 15 and 115 during a study on the diversity of arbuscular fungi in Cameroon. 


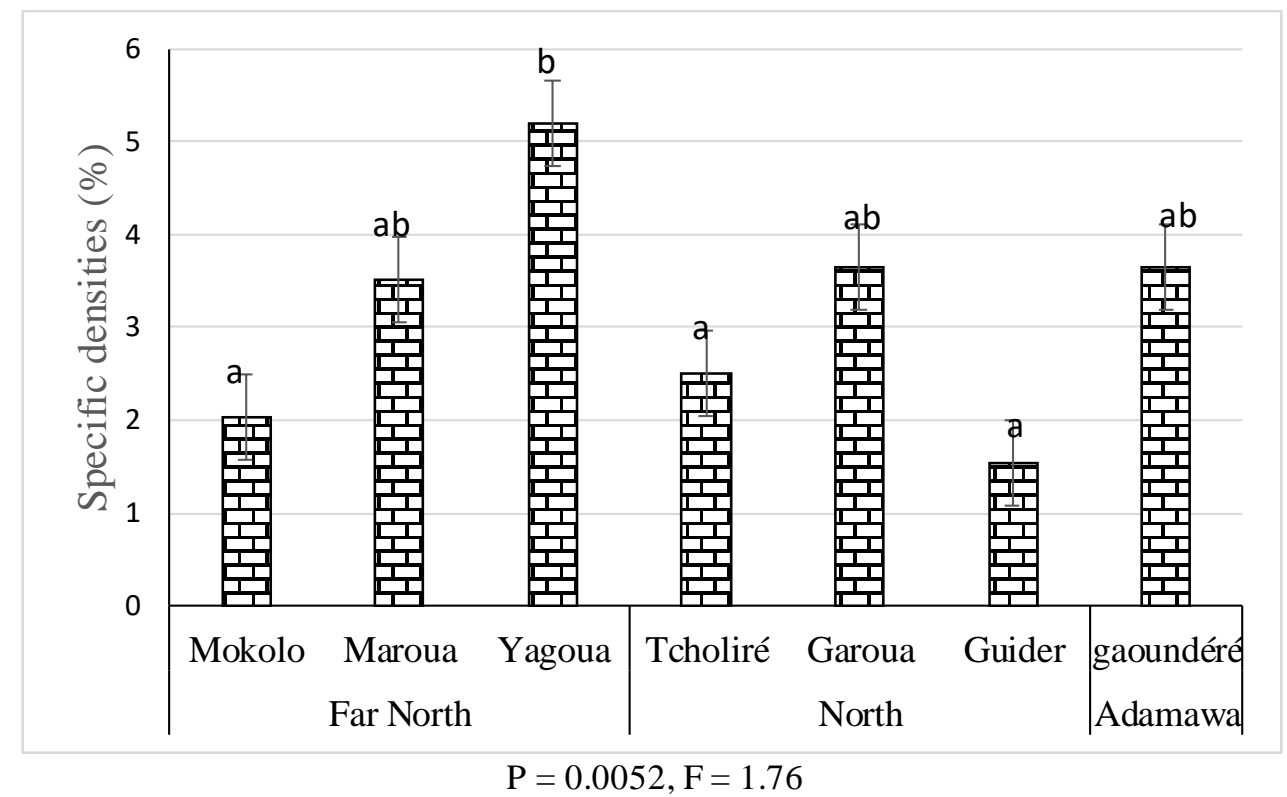

Figure 4: Specific density

Specific density values are the average of three replications. Bars with the same letter are not significantly different at the indicated probability threshold.

\section{Specific richness}

Analysis of the variation in specific diversity (figure 5) reveals that the highest specific richness is that of the Mokolo zone $(8 \%)$ in the Far North, $(\mathrm{p}<0.001)$, followed by those of Yagoua (5\%) and Garoua (5\%), different of the data obtained in the areas of Guider (3\%) and Tcholiré (3\%) which are less. The diversities recorded in Ngaoundéré (4\%) and Maroua
(4\%) are similar and intermediate to the others. These results are lower than those reported by Maurer and al. (2014) who obtained a richness that varies between 10 and $21 \%$ in Switzerland during a study on the effect of cultivation practices on the arbuscular mycorrhiza fungi community. The low diversity in our case can be attributed to the type of agricultural practices and the nature of the soils. In fact, a low specific richness can be attributed to a complex selection pressure by agricultural practices on the communities of CMAs among which, mineral fertilization, tillage, use of pesticides and monoculture, (Helgason and al. (1998).

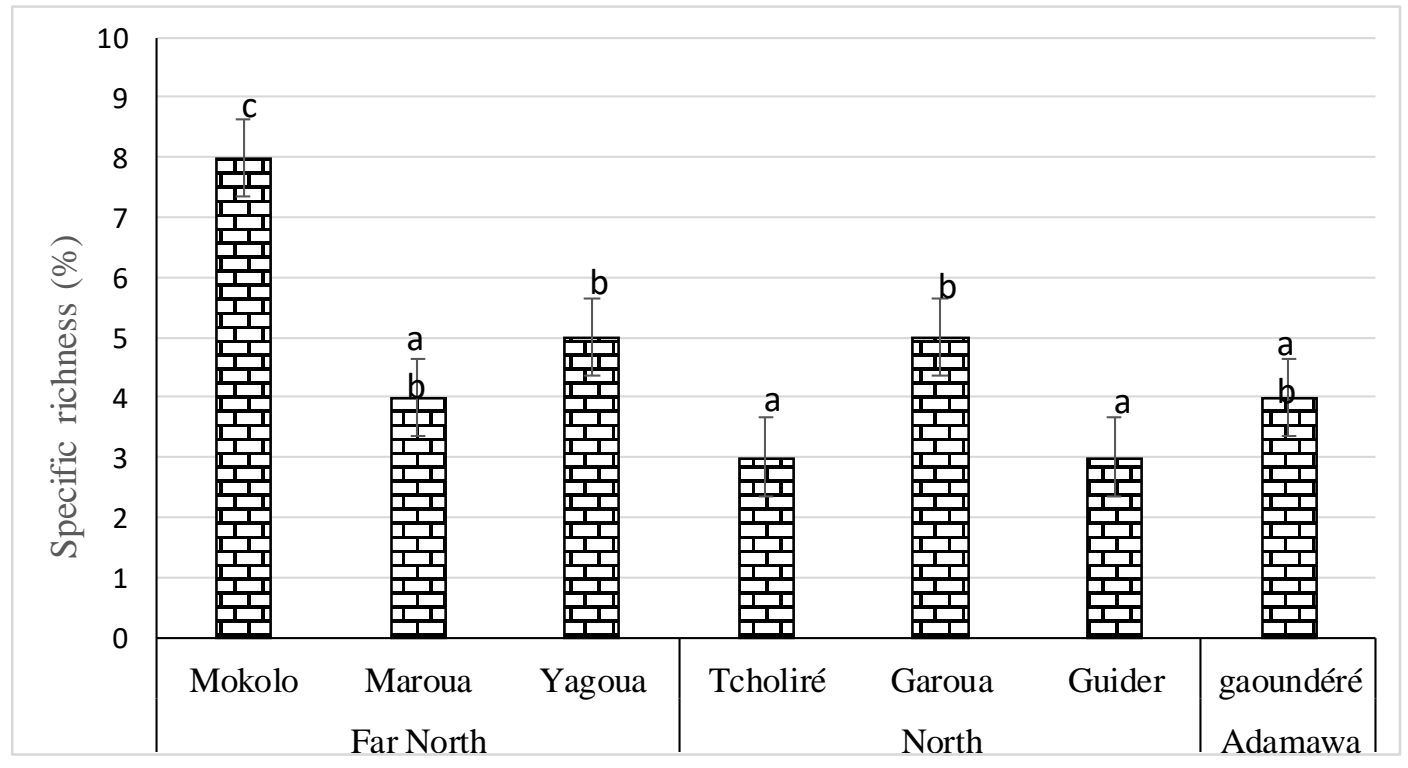

Figure 5: Specific richness 
Prevalence and Morpho-Anatomical Diversity of Arbuscular Mycorrhizal Fungi Spores, from Soybean (Glycine max L.) Rhizosphere in the Agro-Ecological Zone 1 of Cameroon

Specific richness values are the means of three replicates. Bars with the same letter are not significantly different at the indicated probability threshold.

\section{Correlation between the mycorrhization} parameters and the soils physico-chemical properties

It appears that the intensity and frequency of mycorrhization are positively related and the correlation is highly significant $(\mathrm{P}<0.0001, \mathrm{r}=$
0.9968). At contrary, there is a negative and significant correlation between the $\mathrm{pH}$ and the specific density $(r=-0.8089, P=0.02)$. That means that a lower $\mathrm{pH}$ affects negatively soil CMA communities. A negative and significant correlation is also registered betwen the mycorrhizal frequency and the organic matter $(r=-8061, P=0,027)$. Thus, when the soils is wthith hight fertility, the role of mycorrhization symbiosis can be less required and even totaly supress, Tacon and al. (1999). All the others correlations are not significant.

Table 3: Correlation between density and specific richness and the soils physico-chemical properties

\begin{tabular}{|c|c|c|c|c|}
\hline & F (\%) & I (\%) & D (\%) & R (\%) \\
\hline \multirow[t]{3}{*}{$\mathbf{F}(\%)$} & & 0,9968 & 0,0399 & $-0,2540$ \\
\hline & & (7) & (7) & (7) \\
\hline & & 0,000 & 0,9328 & 0,5826 \\
\hline \multirow[t]{3}{*}{ I (\%) } & 0,9968 & & 0,0335 & $-0,3007$ \\
\hline & (7) & & (7) & (7) \\
\hline & $\mathbf{0 , 0 0 0} * * *$ & & 0,9431 & 0,5123 \\
\hline \multirow[t]{3}{*}{ D (\%) } & 0,0399 & 0,0335 & & 0,0304 \\
\hline & (7) & (7) & & (7) \\
\hline & 0,9323 & 0,9431 & & 0,9485 \\
\hline \multirow[t]{3}{*}{$\mathbf{R}(\%)$} & $-0,2540$ & $-0,3007$ & 0,0304 & \\
\hline & (7) & (7) & (7) & \\
\hline & 0,5826 & 0,5123 & 0,9485 & \\
\hline \multirow[t]{3}{*}{ pH } & $-0,3367$ & $-0,3455$ & $-0,8089$ & $-0,0739$ \\
\hline & (7) & (7) & (7) & (7) \\
\hline & 0,4602 & 0,4479 & $0,0276 * *$ & 0,8749 \\
\hline \multirow[t]{3}{*}{$\mathbf{P}$} & 0,4234 & 0,4507 & $-0,2198$ & 0,6600 \\
\hline & (7) & (7) & (7) & (7) \\
\hline & 0,3439 & 0,3101 & 0,6357 & 0,1067 \\
\hline \multirow[t]{3}{*}{$\mathbf{K}$} & 0,4605 & 0,4223 & 0,1857 & $-0,2024$ \\
\hline & (7) & (7) & (7) & (7) \\
\hline & 0,2984 & 0,3453 & 0,6902 & 0,6664 \\
\hline \multirow[t]{3}{*}{ Cond } & 0,6264 & 0,6503 & 0,2352 & 0,3148 \\
\hline & (7) & (7) & (7) & (7) \\
\hline & 0,1323 & 1138 & 0,6116 & 0,4929 \\
\hline \multirow[t]{3}{*}{ Clay } & 0,3676 & 0,3670 & 0,5772 & 0,2795 \\
\hline & (7) & (7) & (7) & (7) \\
\hline & 0,4172 & 0,4180 & 0,1748 & 0,5438 \\
\hline \multirow[t]{3}{*}{ Sand } & $-0,5286$ & $-0,5136$ & $-0,5763$ & 0,2623 \\
\hline & (7) & (7) & (7) & (7) \\
\hline & 0,2225 & 0,2386 & 0,1757 & 0,5698 \\
\hline \multirow[t]{3}{*}{ Mg2+ } & $-0,1453$ & $-0,1010$ & $-0,2778$ & 0,2889 \\
\hline & (7) & (7) & (7) & (7) \\
\hline & 0,7543 & 0,8294 & 0,5464 & 0,5297 \\
\hline \multirow[t]{3}{*}{ M.O } & -8061 & $-0,7671$ & $-0,1699$ & 0,2004 \\
\hline & (7) & (7) & (7) & (7) \\
\hline & $0,0286 * *$ & 0,441 & 0,7158 & 0,6666 \\
\hline \multirow[t]{3}{*}{ C.O } & $-0,6264$ & 0,6503 & 0,2352 & 0,3140 \\
\hline & (7) & (7) & (7) & (7) \\
\hline & 0,1323 & 0,1168 & 0,6116 & 0,4929 \\
\hline
\end{tabular}

$* * *=$ Very highly significant; $* *=$ highly significant; $\mathrm{ns}=$ Not significant; $\mathrm{D}(\%)=$ specific density; $\mathrm{R}(\%)=$ Specific richness; P (mm): Available phosphorus; C.O = Organic carbon, M.O : Organic matters ; Cond : Conductivity 
Prevalence and Morpho-Anatomical Diversity of Arbuscular Mycorrhizal Fungi Spores, from Soybean (Glycine max L.) Rhizosphere in the Agro-Ecological Zone 1 of Cameroon

\section{Morpho-anatomical characterization of endomycorrhiza spores}

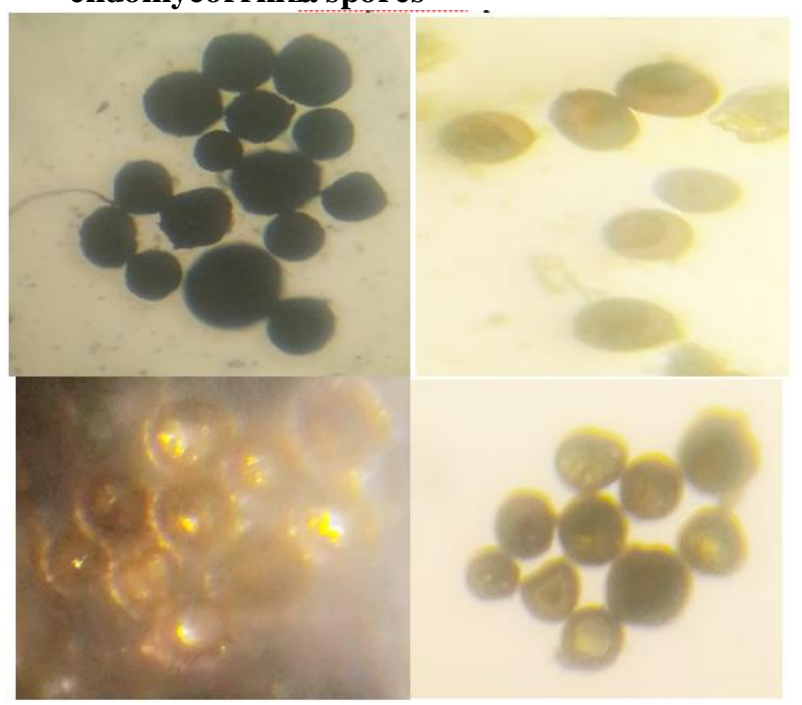

Figure 6 : Freshly extracted spores

a. Septoglomus constrictum (Trappe, 1977)

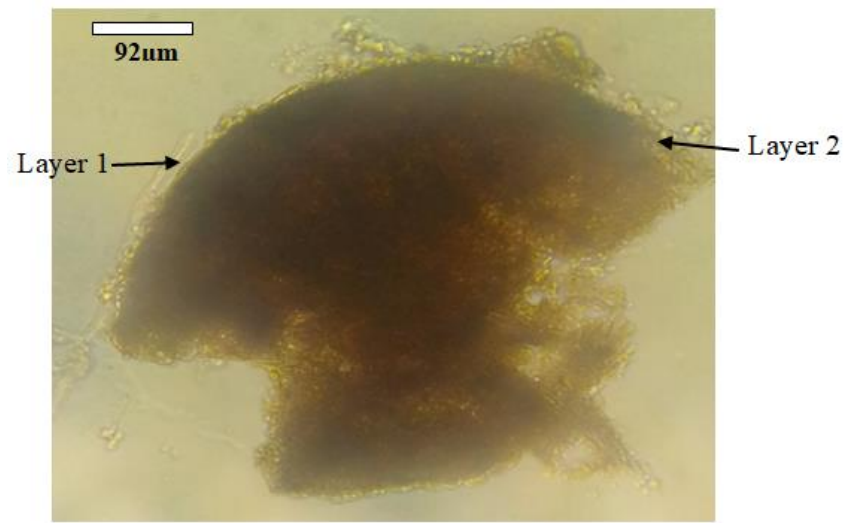

It is a species easies to recognize thanks to the distinctive color of its spores, notably brown-orange to black-brown (Trappe, 1977).

b. Acaulospora kentinensis (Kaonangbua and al., 2010)

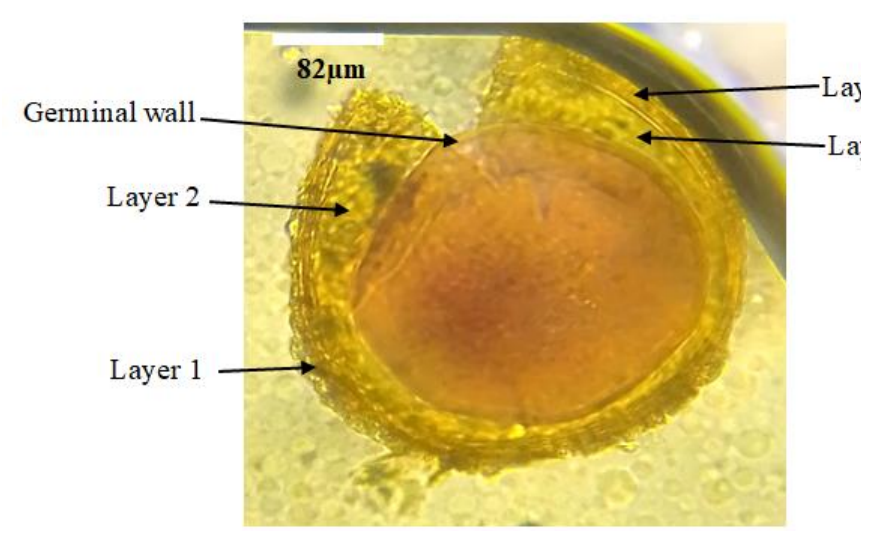

c. Glomus maculosum (Mill and Walker, 1986)

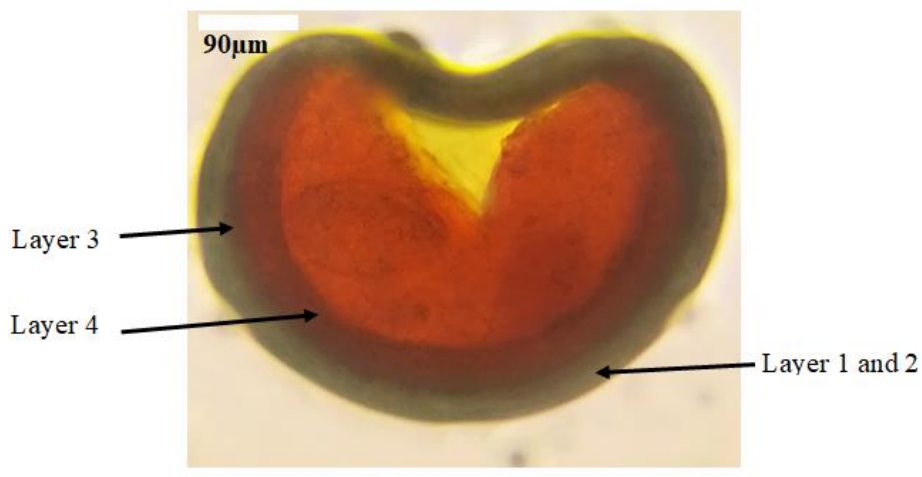

d. Glomus manihotis (Schenk and al., 1984)

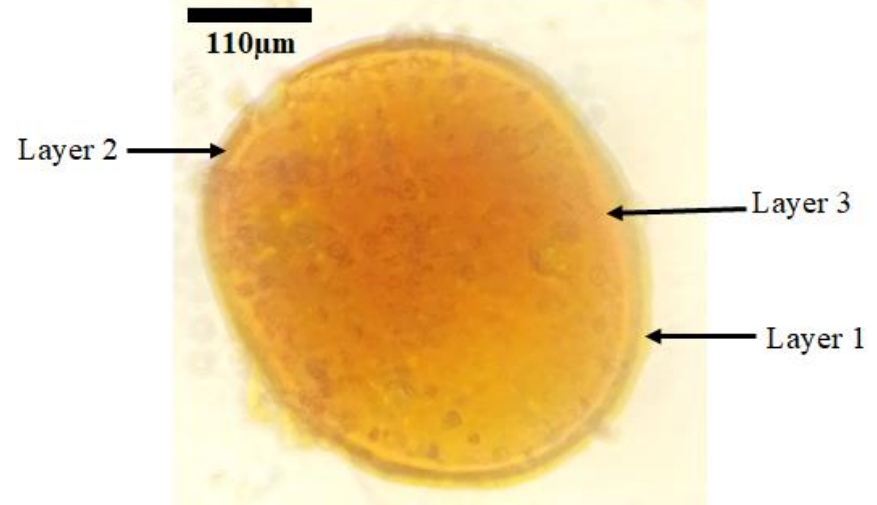

e. Rhizophagus intraradices (Schenk, 1982)

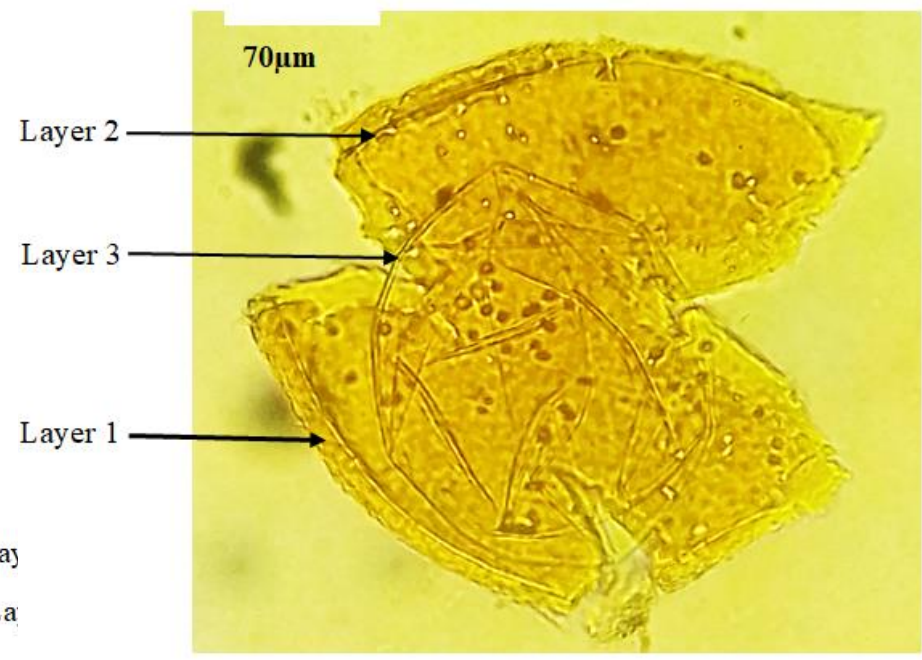

f. Diversispora epigae (Walker and Schubler, 1979) 


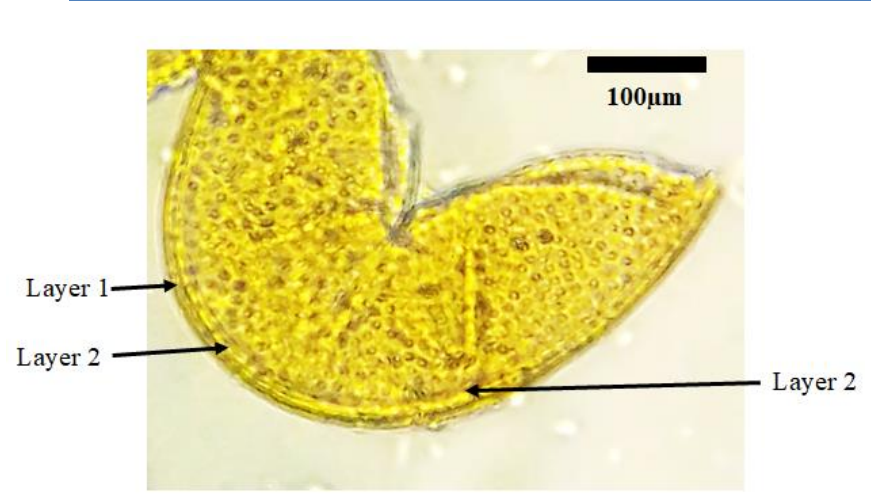

g. Ambispora sp (International Vesicular Mycorrhizal fungi collection (INVAM): http://invam.caf.wv.edu/fungi/ taxonomy/species ID.htm)

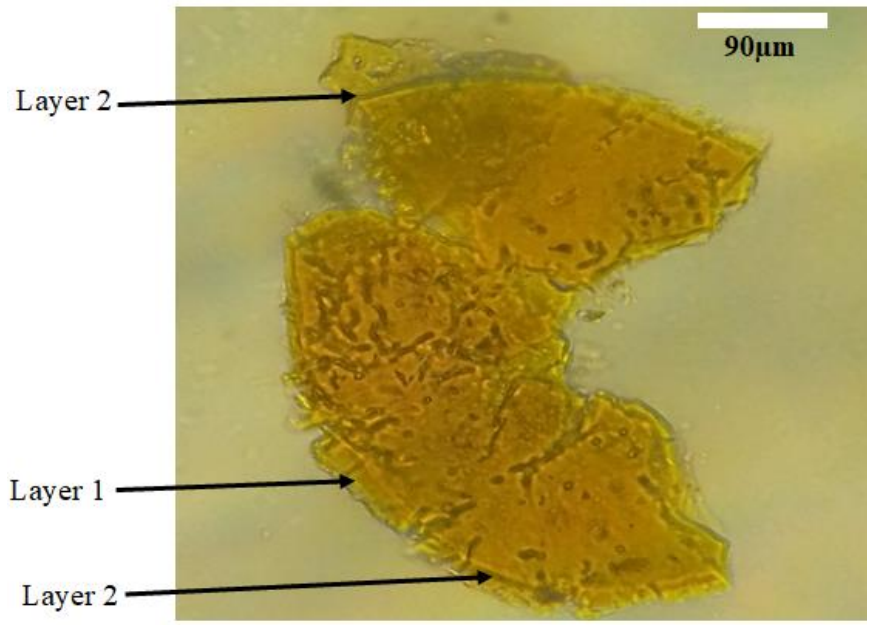

h. Acaulospora myriocarpa (Schenck and al., 1990)

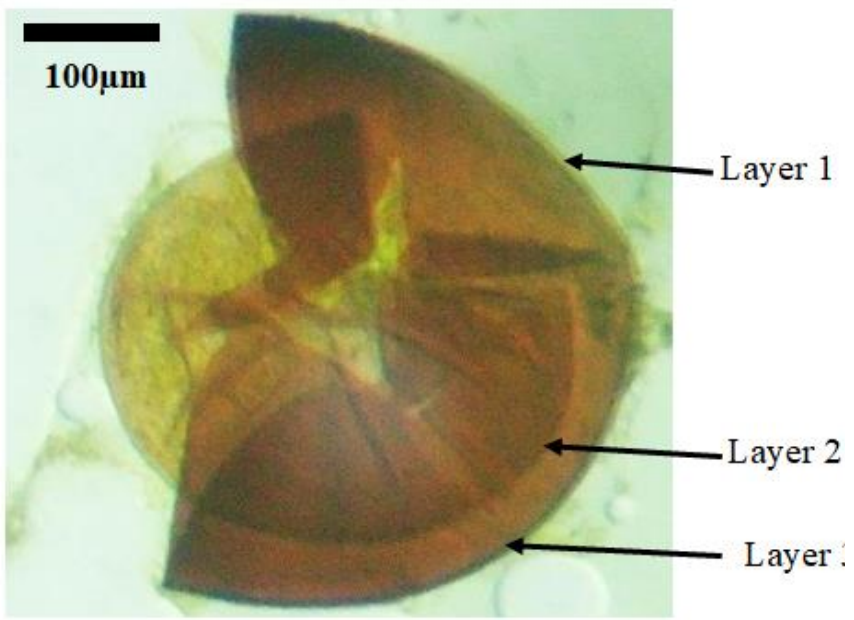

i. Funniliformis mossea (International Vesicular Mycorrhizal fungi collection (INVAM): http://invam.caf.wv.edu/fungi/ taxonomy/species ID.htm)

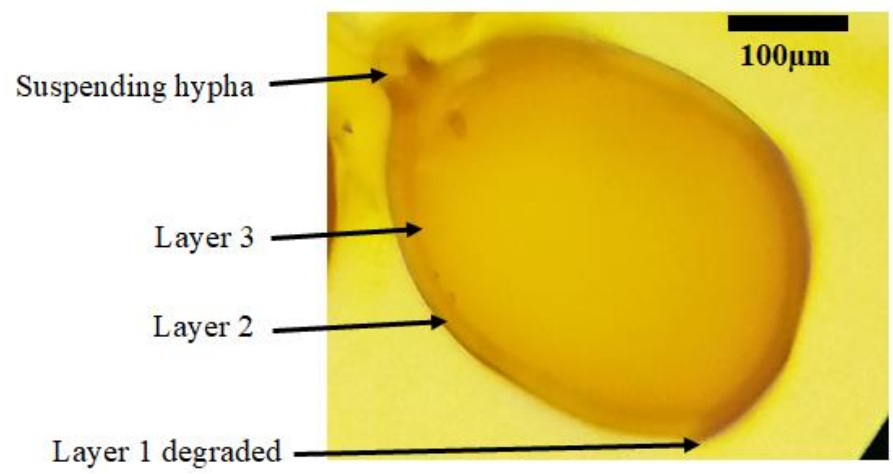

\section{Endomycorrhizal spores distribution}

Table 4 shows the distribution of arbuscular endomycorrhizal fungal spores in the soybean rhizosphere within the study area. It shows that Septoglomus constrictum is the most abundant and representative specimen under soybean in the three regions. It is therefore the ubiquitous specimen of the rhizosphere of the plant under investigation in the agro-ecological zone 1 of Cameroon. Funneliformis mossea, Ambispora sp, Acaulospora myriocarpa are the least abundant.

The Shanonne diversity index is high in the Mokolo zone $\left(\mathrm{H}^{\prime}=0.99\right)$, compared to the other zones showing that its diversity is the highest, while this index is lower in the Bénoué $\left(\mathrm{H}^{\prime}=0.023\right)$ meaning that its diversity is the lowest. Similar results were found by Maurer and al. (2014) in Switzerland who noted that Septoglomus constrictum is the most abundant specimen in cultivated plots. Nadjilom and al. (2019) reported similar results, where they indicated that Septoglomus constrictum is the most abundant specimen of the rhizophere of rice in the Sahelian zone in Chad. 
Prevalence and Morpho-Anatomical Diversity of Arbuscular Mycorrhizal Fungi Spores, from Soybean (Glycine max L.) Rhizosphere in the Agro-Ecological Zone 1 of Cameroon

Table 4: Distribution of spores in the rhizosphere of soybeans in the different departments

\begin{tabular}{|c|c|c|c|c|c|c|c|}
\hline & Mokolo & Maroua & Yagoua & Garoua & Tcholiré & Guider & Ndere \\
\hline G. constrictum & 1381 & 761 & 928 & 979 & 766 & 638 & 986 \\
\hline G. manihostis & 4 & 0 & 5 & 0 & 0 & 0 & 0 \\
\hline R. intraradices & 23 & 92 & 18 & 22 & 14 & 15 & 3 \\
\hline Ambispora & 4 & 0 & 0 & 0 & 0 & 0 & 0 \\
\hline A. myriocarpa & 1 & 0 & 0 & 0 & 0 & 0 & 0 \\
\hline H' & 0,99 & $\mathbf{0 , 3 9}$ & $\mathbf{0 , 2 7}$ & $\mathbf{0 , 0 2 3}$ & 0,12 & $\mathbf{0 , 0 3 5}$ & 0,55 \\
\hline
\end{tabular}

$\mathrm{H}$ ': Shanonne's divrsity Index. The values assigned to each specimen correspond to its number at the end of three extraction operations; Ndéré: Ngaoundéré

\section{Conclusion}

This work aimed to study the diversity of arbuscular mycorrhiza fungus spores native to the soybean rhizosphere in agro-ecological zone I of Cameroon. The morpho-anatomical characterization of the spores indicated the presence of nine different specimens: Septoglomus constrictum, Glomus maculosum, Glomus manihostis, Acaulospora kentinensis, Acaulospore myriocarpa, Rhizophagus intraradices, Ambispora sp, Funneliformis mossea, Diversispora epigae. Among these strains, Septoglomus constrictum is the most abundant specimen while Funneliformis mossea, Ambispora sp and Acaulospora myriocarpa are the rarest. The agronomic performances of these strains can be evaluated for their in the cultivation of soybeans in the agro-ecological zone I of Cameroon.

\section{Bibliographical References}

1. Anissa Lounes-Hadj Sahraoui, 2013. La Mycorhize a arbuscules : quels bénéfices pour I'homme et son environnement dans un contexte de développement durable ? Rev. Sci. Technol., Synthese 26: 06 -19.

2. Genot V., Colinet G., Bock L., 2007. Fertilité du sol agricole et forestier en région Wallone. Dossier scientifique, rapport analytique 2006-2007 sur l'état de l'environnement Wallonne. Faculté universitaire agronomiques de Gembloux, $13 \mathrm{p}$.

3. Głodowska M., Wozniak M., 2019. Changes in Soil Microbial Activity and Community Composition as a Result of Selected Agricultural Practices. Agricultural Sciences, 10 : 330-351.

4. Gnamkoulamba A., Tounou A. K., Tchabi A., Agboka K., Adjévi A. K. M., Batawila K., 2018. Prévalence et diversité des spores des champignons mycorhiziens arbusculaires en culture de riz sous les différents systèmes de culture de riz dans cinq zones agro-écologiques au Togo. Journal of Applied Biosciences, 126: 12647-12664.

5. Helgason T., Daniell T. J., Husban R., Fitter A. H., Young J. P. Y., 1998. Ploughing up the wood-wide web ? Nature, 394 : 431.

6. Kaonongbua W., Morton J. B. \& Bever J. D., 2010 Taxonomic revision transferring species in Kuklospora to Acaulospora (Glomeromycota) and a description of Acaulospora colliculosa sp from field collected spores. Mycologia, 102, 1497-1509.

7. Maurer C., Rüdy M., Chervet A., Sturny W. G., Flisch R. \& Oehl F., 2014. Diversité des champignons mycorhiziens Arbusculaires sous semis direct et sous labour. Recherche Agronomique Suisse, 5 (10) : 398-405.

8. Miller D. D. \& Walker C: 1986. Glomus maculosum sp.nov. (Endogonaceae): an endomycorrhizal fungus. Mycotaxon, $26: 217-227$.

9. Nadjilom Y., Toukam S. T., Tobolbaï R. \& Ngakou1 A.,
2019. Morphological and structural characterization of rhizospheric endomycorrhiza communities associated with rice grown in the sahelian zone (Chad). International Journal of Plant \& Soil Science 31(5): 1-14.

10. Ngonkeu M. E. L., Nwaga D., Adamou S., Fokom R., Tchameni N. S., Onguene N. A., Nana W. L., Chaintreuil C., The C., Amougou A., Moulin L., Prin Y., Lebrun M., Dreyfus B. Diversite des champignons mycorhiziens arbusculaires du cameroun. IRD Editions. Institut de Recherche pour le Développement Marseille, 2013.

11. Ouallal I., Abbas Y., Ech-cheddadi S., Ouajdi M., Ouhadach M., Yacoubi H. E., Kerdouh B., Goumi Y. E., Rochdi A., 2018. Diversité des champignons endomycorhiziens de l'arganier et potentiel mycorhizogène des sols rhizosphériques des arganeraies du Sud-Ouest marocain, Bois et Forêts des Tropiques, $338: 73-86$.

12. Schenck NC. \& Smith GS: 1982. Additional new and unreported species of mycorrhizal fungi (Endogonaceae) from Florida. Mycologia, 74, 77-92.

13. Schenck N. C. \& Smith G. S: 1982. Additional new and unreported species of mycorrhizal fungi (Endogonaceae) from Florida. Mycologia, 74 : 77-92.

14. Schenck NC, Spain JL, Sieverding E. \& Howeler RH: 1984 Several new and unreported vesicular-arbuscular mycorrhizal fungi (Endogonaceae) from Colombia. Mycologia, 76, 685699.

15. Sghir F, Chliyeh M, Kachkouch W, Khouader M, Touhami A, Benkirane R. \& Douira

16. A: 2013. Mycorrhizal status of Olea europaea spp. oleaster in Morocco. Journal of Applied Biosciences, 61, 4478 - 4489.*

17. Schenck NC, Spain JL, Sieverding E. \& Howeler RH: 1984. Several new and unreported vesicular-arbuscular mycorrhizal fungi (Endogonaceae) from Colombia. Mycologia, 76: 685699.

18. Schenck N. C. and Peres Y., 1990. Manual for the identification of VA mycorrhizal fungi, 3rded. Synergistic Publ., Gaines ville, FL.

19. Shannon CE. 1948. A mathematical theory of communications. Bell Systems Technical

20. Journal, 27, 379-423.

21. Tobolbai R., Adamou S., Ngakou A., 2018. Morphological and structural diversities of indigenous endomycorrhiza communities associated to maize [Zea mays (L.)] in Northern Cameroonian soils. Journal of Animal \& Plant Sciences, 38 , (1): 6057-6073

22. Trappe JM: 1977. Three new Endogonaceae: Glomus constrictus, Sclerocystis clavispora, and Acaulospora scrobiculata. Mycotaxon, 6, 359-366.

23. Walker C., 1979. Complexipes moniliformis: A new genus and species tentatively, placed in the Endogonaceae. Mycotaxon, 12 : 99-104.

24. Yolande Dalpé, 2005. Les mycorhizes : un outil de protection des plantes mais non une Panacée. Phytoprotection 86 : 5359

25. Zougari-Elwedi B., Mustapha, Labibdi S., Dalpé Y. \& Lounès-Haj S. A., 2012. Evaluation de la mycorhizaion du palmier dattier (Phoenix dactylifera L.) dans la région du Djérid (1), Sanaa Revue de l'I.N.A.T. Vol $28 n^{\circ} 1$ - juin 2012. 